\title{
Efficiency Enhancement on Thermal Comfort Assessment of Indoor Space with Air-Conditioner Using Computational Analysis
}

\author{
Yu-Tuan Chou, ${ }^{1}$ Shao-Yi Hsia, ${ }^{2}$ and Bi-Wen Lee ${ }^{3}$ \\ ${ }^{1}$ Department of Applied Geoinformatics, Chia Nan University of Pharmacy \& Science, Tainan City 717, Taiwan \\ ${ }^{2}$ Department of Mechanical \& Automation Engineering, Kao Yuan University, Kaohsiung City 821, Taiwan \\ ${ }^{3}$ Department of Tourism Management, Shih Chien University, Kaohsiung City 845, Taiwan
}

Correspondence should be addressed to Shao-Yi Hsia; syhsia@cc.kyu.edu.tw

Received 15 June 2014; Accepted 14 August 2014; Published 25 September 2014

Academic Editor: Teen-Hang Meen

Copyright (C) 2014 Yu-Tuan Chou et al. This is an open access article distributed under the Creative Commons Attribution License, which permits unrestricted use, distribution, and reproduction in any medium, provided the original work is properly cited.

\begin{abstract}
Thermal comfort providing is one of the biggest uses of energy in building. For giving better human comfort, the suitable operation conditions of air-conditioner are the most important. The quick and right approach is necessary. In this paper, a small office is studied to improve office staff staying for a long period of time and achieve the thermal comfort environment for reducing energy consumption. Commercial software, Solidworks, is utilized for modeling the facilities and the Flow Simulation module for analyzing the air properties of the indoor space. Four types of air-conditioner operation are applied to set the simulated conditions, including exterior temperature, outlet temperature and wind speed of air-conditioner, and location of air-conditioner. Predicted mean vote (PMV) and predicted percent dissatisfied (PPD) at specific office areas are further acquired through dynamic anthropometry. For seeking the optimal control factors, both of the full factorial method and Taguchi method are utilized to obtain the PMV of specified location. The analyzed result shows the evaluation speed of indoor thermal comfort by Taguchi method is faster than the fullfactorial method. It is concluded that software simulation with Taguchi method shows the successful implementation and higher efficiency for thermal comfort assessment.
\end{abstract}

\section{Introduction}

National policies in sustainable development and favorable living environments are inevitable for people in the past years. Most importantly, under different environmental requirements and comfort conditions, indoor thermal comfort could be regulated through air-conditioning systems and ventilating equipment with time evolution and technological development. Nevertheless, energy consumption becomes a primary issue for sustainable development. Achieving the favorable comfort and lower energy utilization through the optimal design has become the major concern of many researchers. The environmental climate has changed the conditions of temperature, humidity, and wind direction that people's perceived comfort would be directly affected. In architecture design, air-conditioning or ventilating equipment could be applied to regulating the relative thermal parameters so as to achieve the heat balance of human bodies. It is generally regarded as thermal comfort design. Not until the improvement of heating technology in the end of 18th century and the development of mechanical freeze-drying technique in the beginning of 20th century that the research on thermal comfort was boomed [1].

Thermal comfort assessment is generally considered from human's metabolism, in which the heat could be properly emitted to the environment. It is the so-called human heat balance, where the parameters contain heat production in metabolism, change of heat radiation, heat flow (including breath), heat conduction, and latent heat used in water evaporation process. Each item presents complicated transfer system. Gagge [2] first proposed Generalized Thermal Balance Model in 1936 to establish the balance equation for heat absorption and consumption of human bodies with mathematical model. Such an equation was further 
reinforced and modified for several times and then two approaches for the research on heat balance were appeared. One is Two-Node Model, proposed by Pierce Lab, which sets a node from the center of body to skin and another node from skin to the atmosphere to consider the heat flow direction in the process. The other is Fanger proposed comfort equation [3], which transfers metabolic rate of human bodies into net heating value required for thermal comfort. Appropriately introducing comfort measurement into mathematical equations provides broad research space. Furthermore, comfort covers spiritual satisfaction that both physiological and psychological factors should be considered in the evaluation process [4]. The major factors in the heat dissipation of human bodies are classified as follows.

(1) Environmental factors, including air temperature, wind speed, humidity, and radiation.

(2) Personal factors, containing metabolic rate (under different activities), clothing, health conditions, and environmental adaptation.

(3) Auxiliary factors, covering food and drink, physical appearance, subcutaneous fat, age, and gender.

Most evaluation indicators need to match with the measurement of temperature and wind speed at regional spots and the questionnaire content to achieve specific regional thermal comfort. For instance, Lin et al. [5] measured the thermal comfort of a briefing room in a university and calculated the indoor comfort to establish the reference for domestic thermal comfort. Cheng et al. [6] monitored the thermal environments with and without shelters on a university campus and investigated subjective questionnaire data and objective field measurement that tree shadow could effectively enhance thermal comfort. Nonetheless, such research was restricted in the quantity and setting of equipment that large-area measurement could not be proceeded. Meanwhile, the environmental factors could not be controlled according to the research's requirements. Some researchers, with numerical analyses, therefore predicted the properties of air in specific space with computational fluid dynamics (CFD).

There have been some research results with CFD. Cheng et al. [7] reviewed thermal comfort model in 2012, explained the relative contents, and preceded the numerical analysis of a small-scale office with CFD. Chiang et al. [8] evaluated thermal comfort in the offices in subtropical regions by floor cooling and mechanical ventilating systems. Such analyzed results and design conditions could effectively enhance energy use efficiency and thermal comfort [9].

Although the above methods could rapidly calculate the simulated value, the number of simulation times was so many that it took more time in such a full-factorial experiment. A lot of researchers therefore applied Taguchi Quality Engineering to the studies. Ismail et al. [10] utilized Taguchi methods for optimizing thermal comfort evaluation and environmental factors to ensure the effects of environmental factors of luminance (lux), relative humidity (\%), and WBGT $\left({ }^{\circ} \mathrm{C}\right)$ on the productivity of mobile manufacturers in Malaysia. Chlela et al. [11] simplified the design process to design low energy consumption buildings. Summing up the above explanations,
Taguchi Quality Engineering has been gradually developed. In this paper, digital 3D model of a small office is used for constructing the interior objects and numerical simulation instrument for engineering is introduced to analyze the temperature and wind speed at various locations in a space so as to acquire the full-factorial PMV, which is further compared with Taguchi Quality Engineering to verify the applicability of Taguchi methods in this experiment. The airconditioned system control conditions in such a space are then acquired for estimating the thermal comfort of the office.

\section{Research Principle}

Taking a real small office as the research subject, the temperature, wind speed, and humidity at discrete points, under distinctly designed conditions, are acquired through the procedure of CFD. PMV and PPD of thermal comfort are further calculated to evaluate the thermal comfort of the office. PMV and Taguchi Quality Engineering are further utilized for the evaluation, which is used for comparing the difference in the optimization design process.

In the fluid mechanics, the flow characteristics can be derived by three governing equations, which are as follows:

(a) conservation of mass

$$
\frac{\partial \rho_{m}}{\partial t}+\frac{\partial\left(\rho_{m} u_{f}\right)}{\partial x_{f}}=0
$$

(b) momentum equations

$$
\begin{aligned}
& \frac{\partial\left(\rho_{m} u_{i}\right)}{\partial t}+\frac{\partial\left(\rho_{m} u_{i} u_{f}\right)}{\partial x_{f}} \\
& =\frac{\partial}{\partial x_{f}}\left[\mu_{\text {eff }} \frac{\partial u_{i}}{\partial x_{f}}\right]-\frac{\partial p}{\partial x_{i}}+\rho_{m} B_{i}+S_{u_{i}},
\end{aligned}
$$

(c) energy equation (temperature form)

$$
\frac{\partial\left(\rho_{m} T\right)}{\partial t}+\frac{\partial\left(\rho_{m} u_{f} T\right)}{\partial x_{f}}=\frac{\partial}{\partial x_{f}}\left[\frac{k_{\mathrm{eff}}}{C_{\mathrm{pm}}} \frac{\partial T}{\partial x_{f}}\right]+\frac{Q^{\prime \prime \prime}}{C_{\mathrm{pm}}},
$$

where $\rho_{m}$ is the density of the control volume for the flow; $u_{f}$ is the flow velocity component of each direction; $x_{f}$ is the position vector of the flow field; $u_{\text {eff }}$ is the effective viscosity; $p$ is the pressure value; $B_{i}$ is the body force for each direction; $S_{u i}$ is the loading of three directions; $T$ is the temperature; $k_{\text {eff }}$ is the effective thermal conductivity; $Q$ is the internal heat generation; $C_{\mathrm{pm}}$ is the specified heat at constant pressure.

The factors in thermal comfort of human bodies contain physiological and psychological factors, which are rather complicated. Nevertheless, most standards for thermal comfort are referred to ISO 7730 [12] of International Organization for Standardization and ASHRAE Standard 55 [13] of American Society of Heating, Refrigerating, and AirConditioning Engineers, where PMV and PPD are focused [14]. Moreover, in the PMV model promoted by Fanger, PMV was divided into seven scales, according to the thermal perception of human bodies. 
The PMV relationship could be derived through different deduction as

$$
\begin{aligned}
& \text { PMV } \\
& =\left[0.352 \exp \left(-0.042 \frac{M}{A_{D}}\right)+0.032\right] \\
& \times\left\{\frac{M}{A_{D}}(1-\eta)-0.35\left[43-0.061 \frac{M}{A_{D}}(1-\eta)-p_{a}\right]\right. \\
& -0.42\left[\frac{M}{A_{D}}(1-\eta)-50\right]-0.0023 \frac{M}{A_{D}}\left(44-p_{a}\right) \\
& -0.0014 \frac{M}{A_{D}}\left(34-t_{a}\right) \\
& -3.4 \cdot 10^{-8} f_{\mathrm{cl}}\left[\left(t_{\mathrm{cl}}+273\right)^{4}-\left(t_{r}+273\right)^{4}\right] \\
& \left.+f_{\mathrm{cl}} h_{c}\left(t_{\mathrm{cl}}-t_{a}\right)\right\} \text {, }
\end{aligned}
$$

where $t_{\mathrm{cl}}$ is acquired with iteration, as below

$$
\begin{aligned}
t_{\mathrm{cl}}=35.7-0.032 & \frac{M}{A_{D}}(1-\eta) \\
-0.18 I_{\mathrm{cl}} & \left\{3.4 \cdot 10^{-8} f_{\mathrm{cl}}\left[\left(t_{\mathrm{cl}}+273\right)^{4}-\left(t_{r}+273\right)^{4}\right]\right. \\
& \left.+f_{\mathrm{cl}} h_{c}\left(t_{\mathrm{cl}}-t_{a}\right)\right\} .
\end{aligned}
$$

And the PPD is defined as

$$
\mathrm{PPD}=95 \exp \left(-0.03353 \mathrm{PMV}^{4}-0.2179 \mathrm{PMV}^{2}\right) .
$$

A space in a working environment is designed for use or operation that the size is designed according to human bodies at various states. The physical size of human bodies is generally divided into static anthropometry and dynamic anthropometry. The latter aims to measure the activity angle and stretch space physically under fixed standard posture or working states that it could be the design reference of machines and working environments.

Considering the office staff staying in a small space for a long period of time, the area is set with the coverage of dynamic measurement. The highest sitting posture of human bodies with rising hands could reach $167.8 \mathrm{~cm}$. At the working status, the circular radius for fist exercise with shoulder width reaches $97.5 \mathrm{~cm}$. The cylinder areas formed by the above two sizes become the volume coverage to evaluation regional PMV. After acquiring the values of PMV and PPD of various nodes in the cylinder, the mean is acquired for the comfort evaluation.

In the Taguchi experimental design [15], the quantified experimental results are called the quality characteristics, which can achieve the ideal target by determining the control factors in the parameter design. In order to solve a problem, an engineer needs to definitely understand the quality characteristics of products and the problem and list the factor levels in quality characteristics with a fishbone diagram or

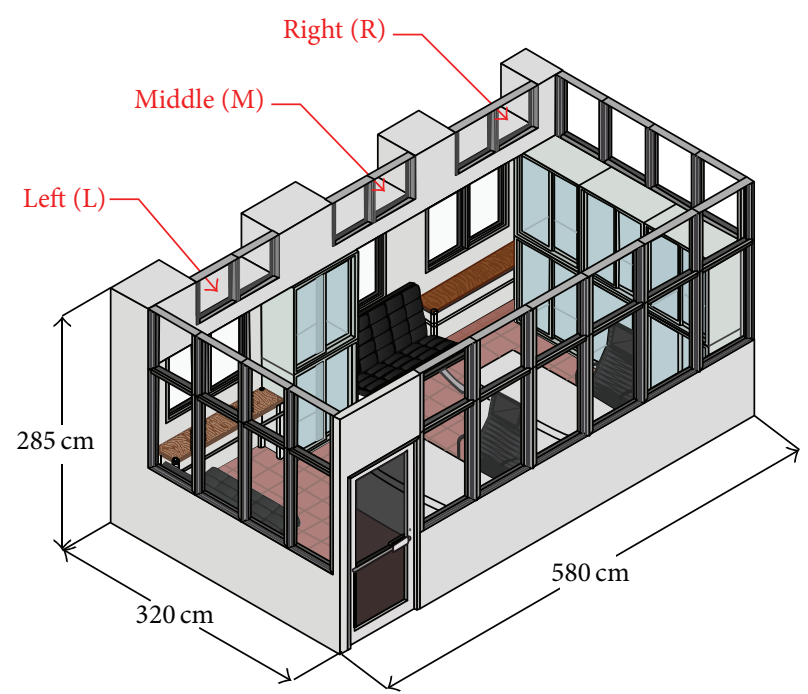

FIGURE 1: 3D model of configuration for the specified small office.

the equivalent method. To achieve the experiment with the most efficient cost, the orthogonal array is selected based on the control factors and the levels, attempting to achieve the required quality characteristics with the most precise experiment. The experimental data are further analyzed with factor reaction analysis and analysis of variance to adjust the control factors, allowing the quality characteristics approaching the deal function to be the optimal design. The orthogonality in an orthogonal array presents the same frequency in all level combinations between two rows in the experimental design. In this research, the orthogonal array L9 $\left(3^{4}\right)$ is used to evaluate the optimal design of indoor thermal comfort. There are 4 factors with 3 levels for 9 sets of experiment. The predicted value of PMV can be calculated by the additive model as

$$
\eta\left(\mathrm{A}_{i}, \mathrm{~B}_{j}, \mathrm{C}_{k}, \mathrm{D}_{m}\right)=\eta_{\mathrm{A} i}+\eta_{\mathrm{B} j}+\eta_{\mathrm{C} k}+\eta_{\mathrm{D} m}-3 \bar{\eta},
$$

where $\eta_{\mathrm{A} i}, \eta_{\mathrm{B} j}, \eta_{\mathrm{C} k}$, and $\eta_{\mathrm{D} m}$ are the reaction value with respect to $A, B, C$, and $D$ factor. $\bar{\eta}$ is the average for total reaction value.

\section{Research Method}

The 3D configuration of a small office is shown in Figure 1. There are two desks, four cabinets, two sofa chairs, and two working counters are covered. Two working staff members are sitting at the desks, where there are the heat source and the comfort evaluation area. Three air-conditioners are about to be equipped on top of the room for evaluating the comfort with distinct locations and wind speed. The air outlets are on the top right of the air-conditioners, and merely the bottom of the door shows the air breather.

Furniture in an office is quite complicated because of the aesthetics, appearance, and materials. Nevertheless, such facilities are not the heat source. Since the analysis in this study is preceded under low wind speed, the detailed sizes 


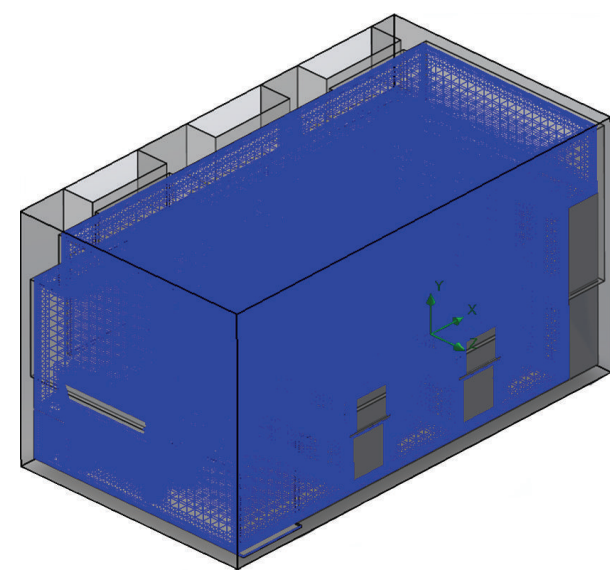

(a) Fluid cells (220547)

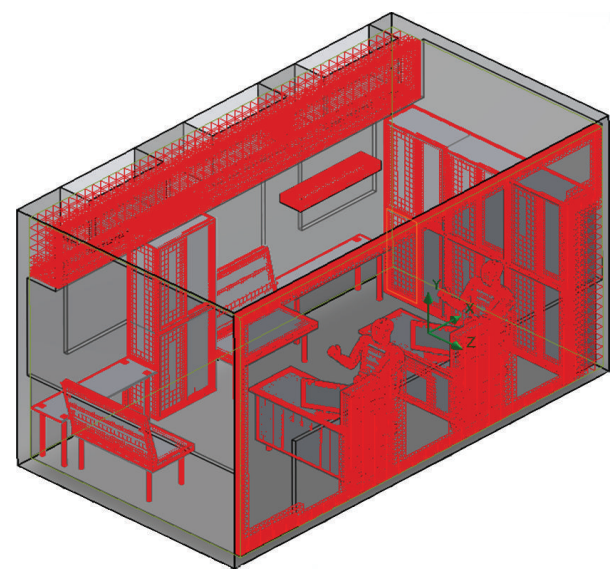

(b) Solid cells (200733)

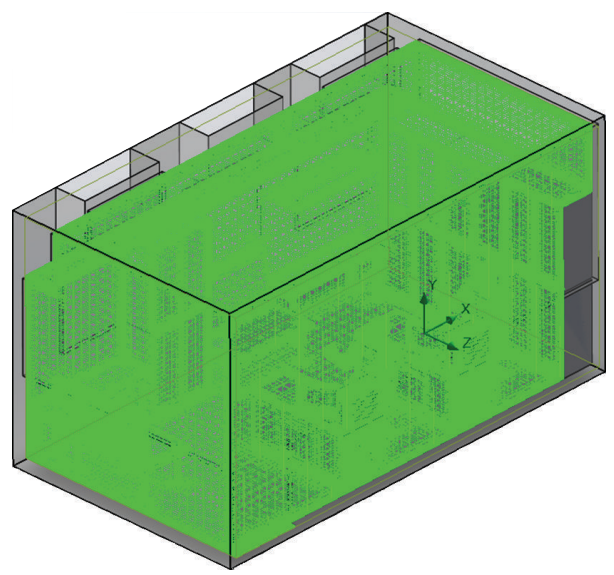

(c) Partial cells (227166)

FIGURE 2: Three types of cell for considering the couple effect between solid and fluid.

and materials show slight influence. There are four heat sources in the studied office, including the following:

(1) metabolic heat power $144 \mathrm{~W}$ of each working staff member,

(2) dissipated heat power $100 \mathrm{~W}$ of each computer,

(3) dissipated heat power $30 \mathrm{~W}$ of each LCD display,

(4) energy consumption $80 \mathrm{~W}$ of a light.

Solidworks Flow Simulation is calculated by segmenting space value with finite volume. The meshes, as shown in Figure 2, are classified into fluid cell for calculating the physical characteristics of fluid, solid cell for defining boundary conditions, and partial cell for setting heat conductive characteristics so as to analyze the algorithm. The set of convergent conditions include operating temperature (OT), wind speed, and mean radiant temperature (MRT), and the values in the calculation process are converged with iteration.

To evaluate the effects of the air-conditioned system distribution in the office on thermal comfort of the staff, outdoor temperature and the three air-conditioned operating conditions are calculated by simulation, as follows:

(1) outdoor temperatures, $30^{\circ} \mathrm{C}, 32^{\circ} \mathrm{C}$, and $34^{\circ} \mathrm{C}$,

(2) positions of air outlets on the air-conditioners, left (L), middle $(\mathrm{M})$, and right $(\mathrm{R})$ on top of the room,

(3) measured wind speed at the air outlets of airconditioners, $6 \mathrm{~m} / \mathrm{s}, 8 \mathrm{~m} / \mathrm{s}$, and $10 \mathrm{~m} / \mathrm{s}$,

(4) measured temperature at the air outlets of airconditioners, $15^{\circ} \mathrm{C}, 17.5^{\circ} \mathrm{C}$, and $20^{\circ} \mathrm{C}$.

Traditionally, the characteristics of thermal comfort in each operating condition should be derived using fullfactorial experiment method; $3^{4}=81$ sets of experiments or events are required. Aiming at the efficient approach for the thermal comfort assessment, Taguchi Quality Engineering is utilized for the analysis. First, through the above cases and operating conditions, the orthogonal array is designed with $4 \times 3$ factors for the stability of the system, and $\mathrm{L}_{9}\left(3^{4}\right)$ orthogonal arrays are selected for total 9 sets of experiments. Next, the thermal comfort indices, PMV and PPD, are 


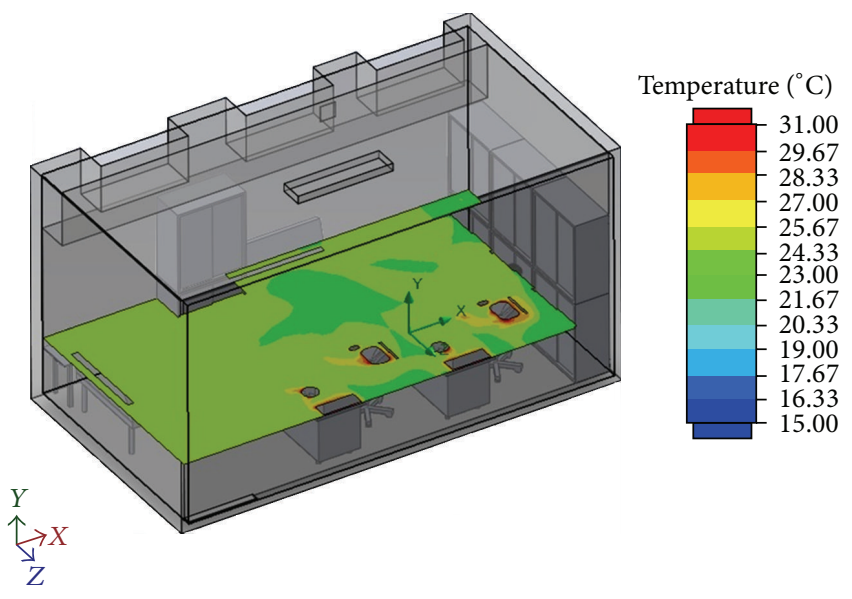

FIGURE 3: Temperature distribution at plane section, height $=$ $0.75 \mathrm{~m}$.

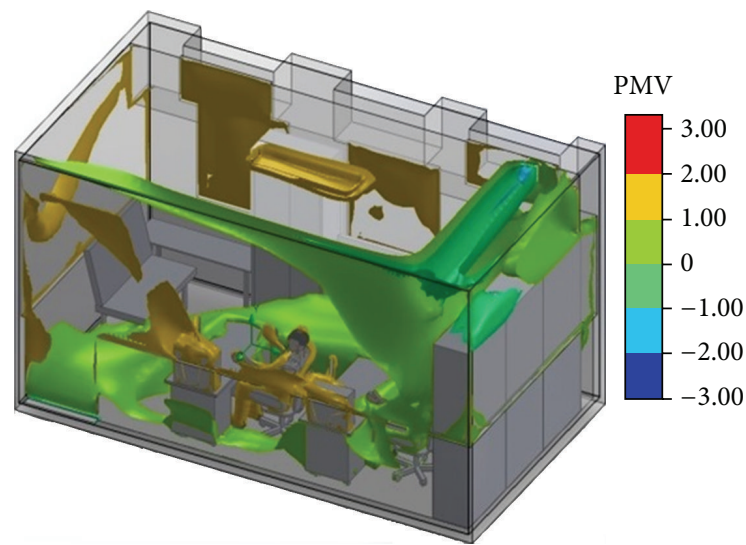

FIgURE 4: Envelope of PMV value at the air-conditioned operation.

analyzed for the specified region. Finally, the difference of PMV for two approaches is compared to show the efficiency of Taguchi method.

\section{Result and Discussion}

Through the above procedure and the analysis with Solidworks Flow Simulation, the temperature, wind speed, surrounding temperature (heat radiation), and humidity in the space and the boundary could be calculated for extracting the physical conditions in the meshes in a specific area. Figure 3 shows the obtained results for the specified height $h=0.75 \mathrm{~m}$. PMV and PPD, introduced in research principle, are used for the evaluation. The analyzed PMV envelope is illustrated in Figure 4 . The operation of air-conditioning systems at two locations is analyzed as follows.

4.1. Computational Results following Taguchi Method. From thermal comfort analysis, PMV $=-3,-2,-1,0,1,2,3$, in which the negative values show the chill feeling, the positive values reveal the heat, and 0 presents the appropriateness. Under the four control factors, PMV appears between positive and

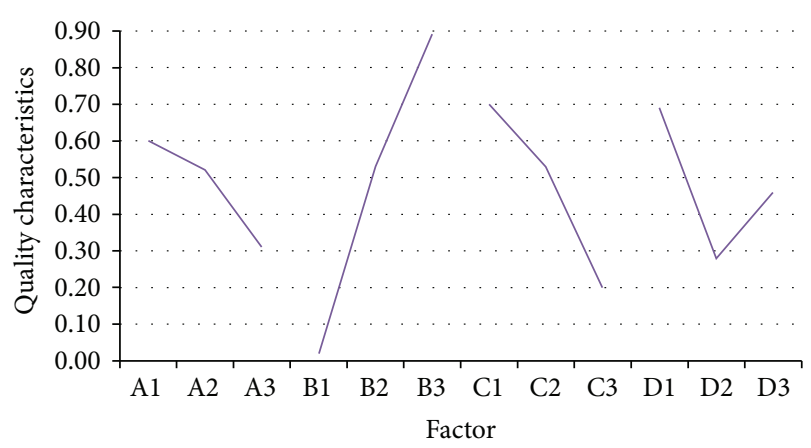

FIGURE 5: Factor reactions of quality characteristics at the front seat.

negative 1 when the air-conditioner operates at $15^{\circ} \mathrm{C}$ and $17.5^{\circ} \mathrm{C}$, showing comfortable condition. For the analyzing airconditioner conditions, outer wall $30^{\circ} \mathrm{C}$, air outlet temperature $15^{\circ} \mathrm{C}$, air speed $10 \mathrm{~m} / \mathrm{s}$ and top right location, PMV at the front seat approaches 0 . Applying Taguchi methods to analyze the simulation values, the mean of Nominal the Best for the experiment can be obtained. The reaction of mean factors acquired by calculating the front seat is shown in Figure 5, in which the air-conditioner temperature is the major factor in the experiment, followed by wind speed, and outdoor temperature shows the least effects.

4.2. PMV Value Prediction by Taguchi Method. PMV at the front seat approaches 0 under the same settings of outer wall temperature $30^{\circ} \mathrm{C}$, air-conditioner temperature $15^{\circ} \mathrm{C}$, wind speed at the outlet air $10 \mathrm{~m} / \mathrm{s}$, and the air-conditioner on the top right of the office. Under the four control factors, PMV value is fluctuated between +1 to -1 , when the air-conditioner also operates at $15^{\circ} \mathrm{C}$ and $17.5^{\circ} \mathrm{C}$, presenting the PMV indicator of thermal comfort. Consequently, outer wall $32^{\circ} \mathrm{C}$, air outlet temperature $15^{\circ} \mathrm{C}$, air speed $8 \mathrm{~m} / \mathrm{s}$ and top right location for the air-conditioner operation; PMV approaches 0 (Table 1), revealing the air-conditioned operation conditions using full-factor method. Applying Taguchi methods to analyze the simulation value and using the mean of Nominal the Best for the experiment, the result is similar to the fullfactor as in Table 2. And the PMV difference between fullfactorial method and Taguchi method is shown in Table 3. By comparing the PMV value from three table, it is proven that Taguchi methods could be utilized for indoor thermal comfort assessment. The number of times and time of the simulation could therefore be significantly reduced, and the full-factor value could be directly acquired through Taguchi methods.

\section{Conclusion}

Aiming at a small-scale office, Solidworks is utilized for the facility modeling to discuss the comfort evaluation under distinct operation conditions, and both full-factorial method and Taguchi method are applied. According to the above analyses and research results, the following conclusions are organized. 
TABLE 1: The simulated PMV value using full-factorial method.

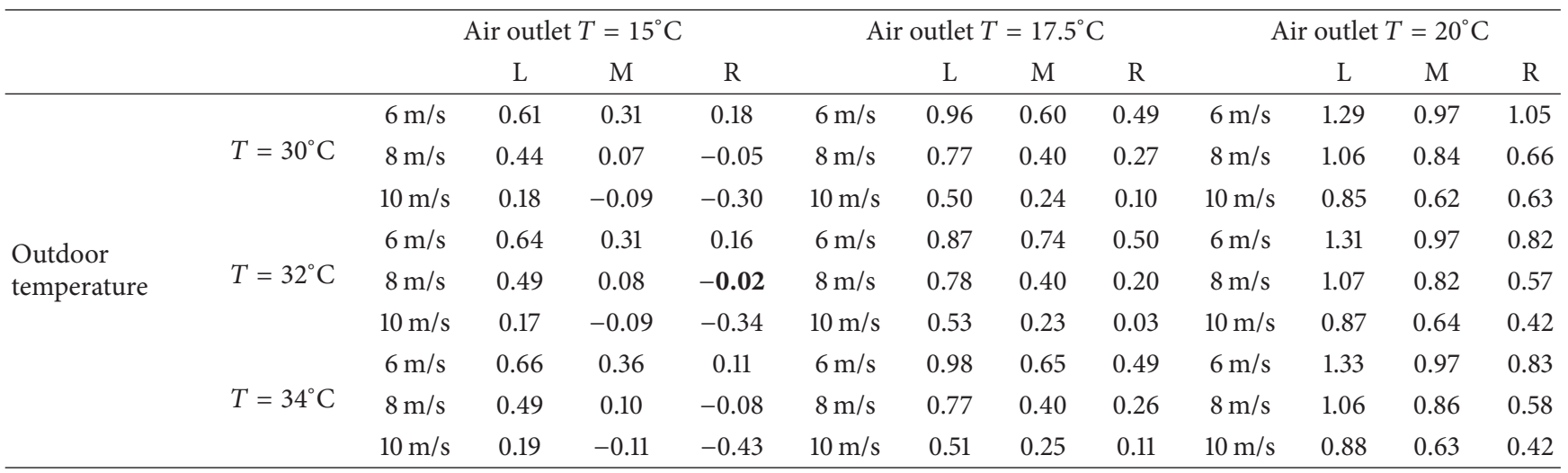

TABLE 2: The predicted PMV value using Taguchi method.

\begin{tabular}{|c|c|c|c|c|c|c|c|c|c|c|c|c|c|}
\hline & & \multicolumn{4}{|c|}{ Air outlet $T=15^{\circ} \mathrm{C}$} & \multicolumn{4}{|c|}{ Air outlet $T=17.5^{\circ} \mathrm{C}$} & \multicolumn{4}{|c|}{ Air outlet $T=20^{\circ} \mathrm{C}$} \\
\hline & & & $\mathrm{L}$ & M & $\mathrm{R}$ & & $\mathrm{L}$ & M & $\mathrm{R}$ & & $\mathrm{L}$ & M & $\mathrm{R}$ \\
\hline \multirow{9}{*}{$\begin{array}{l}\text { Outdoor } \\
\text { temperature }\end{array}$} & \multirow{3}{*}{$T=30^{\circ} \mathrm{C}$} & $6 \mathrm{~m} / \mathrm{s}$ & 0.61 & 0.30 & 0.17 & $6 \mathrm{~m} / \mathrm{s}$ & 0.92 & 0.61 & 0.49 & $6 \mathrm{~m} / \mathrm{s}$ & 1.27 & 0.95 & 0.83 \\
\hline & & $8 \mathrm{~m} / \mathrm{s}$ & 0.40 & 0.09 & -0.04 & $8 \mathrm{~m} / \mathrm{s}$ & 0.71 & 0.40 & 0.28 & $8 \mathrm{~m} / \mathrm{s}$ & 1.06 & 0.74 & 0.62 \\
\hline & & $10 \mathrm{~m} / \mathrm{s}$ & 0.20 & -0.11 & -0.24 & $10 \mathrm{~m} / \mathrm{s}$ & 0.51 & 0.20 & 0.08 & $10 \mathrm{~m} / \mathrm{s}$ & 0.86 & 0.54 & 1.72 \\
\hline & \multirow{3}{*}{$T=32^{\circ} \mathrm{C}$} & $6 \mathrm{~m} / \mathrm{s}$ & 0.63 & 0.31 & 0.19 & $6 \mathrm{~m} / \mathrm{s}$ & 0.94 & 0.63 & 0.50 & $6 \mathrm{~m} / \mathrm{s}$ & 1.28 & 0.97 & 0.85 \\
\hline & & $8 \mathrm{~m} / \mathrm{s}$ & 0.42 & 0.10 & -0.02 & $8 \mathrm{~m} / \mathrm{s}$ & 0.73 & 0.42 & 0.29 & $8 \mathrm{~m} / \mathrm{s}$ & 1.07 & 0.76 & 0.64 \\
\hline & & $10 \mathrm{~m} / \mathrm{s}$ & 0.22 & -0.10 & -0.22 & $10 \mathrm{~m} / \mathrm{s}$ & 0.53 & 0.22 & 0.09 & $10 \mathrm{~m} / \mathrm{s}$ & 0.87 & 0.56 & 0.44 \\
\hline & \multirow{3}{*}{$T=34^{\circ} \mathrm{C}$} & $6 \mathrm{~m} / \mathrm{s}$ & 0.61 & 0.30 & 0.18 & $6 \mathrm{~m} / \mathrm{s}$ & 0.93 & 0.61 & 0.49 & $6 \mathrm{~m} / \mathrm{s}$ & 1.27 & 0.96 & 0.83 \\
\hline & & $8 \mathrm{~m} / \mathrm{s}$ & 0.40 & 0.09 & -0.03 & $8 \mathrm{~m} / \mathrm{s}$ & 0.72 & 0.40 & 0.28 & $8 \mathrm{~m} / \mathrm{s}$ & 1.06 & 0.75 & 0.62 \\
\hline & & $10 \mathrm{~m} / \mathrm{s}$ & 0.20 & -0.11 & -0.23 & $10 \mathrm{~m} / \mathrm{s}$ & 0.52 & 0.20 & 0.08 & $10 \mathrm{~m} / \mathrm{s}$ & 0.86 & 0.55 & 0.42 \\
\hline
\end{tabular}

TABLE 3: The analyzed PMV difference between full-factorial method and Taguchi method.

\begin{tabular}{|c|c|c|c|c|c|c|c|c|c|c|c|c|c|}
\hline & & \multicolumn{4}{|c|}{ Air outlet $T=15^{\circ} \mathrm{C}$} & \multicolumn{4}{|c|}{ Air outlet $T=17.5^{\circ} \mathrm{C}$} & \multicolumn{4}{|c|}{ Air outlet $T=20^{\circ} \mathrm{C}$} \\
\hline & & & $\mathrm{L}$ & M & $\mathrm{R}$ & & $\mathrm{L}$ & M & $\mathrm{R}$ & & $\mathrm{L}$ & $\mathrm{M}$ & $\mathrm{R}$ \\
\hline \multirow{9}{*}{$\begin{array}{l}\text { Outdoor } \\
\text { temperature }\end{array}$} & \multirow{3}{*}{$T=30^{\circ} \mathrm{C}$} & $6 \mathrm{~m} / \mathrm{s}$ & 0.00 & 0.09 & -0.01 & $6 \mathrm{~m} / \mathrm{s}$ & -0.03 & 0.03 & 0.00 & $6 \mathrm{~m} / \mathrm{s}$ & -0.04 & 0.05 & 0.02 \\
\hline & & $8 \mathrm{~m} / \mathrm{s}$ & 0.03 & 0.06 & 0.01 & $8 \mathrm{~m} / \mathrm{s}$ & 0.00 & 0.00 & 0.05 & $8 \mathrm{~m} / \mathrm{s}$ & 0.05 & 0.06 & 0.03 \\
\hline & & $10 \mathrm{~m} / \mathrm{s}$ & -0.01 & 0.01 & -0.06 & $10 \mathrm{~m} / \mathrm{s}$ & -0.01 & 0.05 & -0.03 & $10 \mathrm{~m} / \mathrm{s}$ & 0.02 & 0.09 & 0.00 \\
\hline & \multirow{3}{*}{$T=32^{\circ} \mathrm{C}$} & $6 \mathrm{~m} / \mathrm{s}$ & -0.01 & 0.09 & -0.05 & $6 \mathrm{~m} / \mathrm{s}$ & -0.05 & 0.00 & -0.02 & $6 \mathrm{~m} / \mathrm{s}$ & -0.04 & 0.00 & -0.01 \\
\hline & & $8 \mathrm{~m} / \mathrm{s}$ & -0.02 & -0.01 & 0.00 & $8 \mathrm{~m} / \mathrm{s}$ & -0.05 & 0.00 & 0.01 & $8 \mathrm{~m} / \mathrm{s}$ & -0.02 & 0.01 & -0.01 \\
\hline & & $10 \mathrm{~m} / \mathrm{s}$ & -0.05 & 0.00 & -0.10 & $10 \mathrm{~m} / \mathrm{s}$ & 0.00 & 0.01 & -0.05 & $10 \mathrm{~m} / \mathrm{s}$ & 0.03 & 0.06 & 0.01 \\
\hline & \multirow{3}{*}{$T=34^{\circ} \mathrm{C}$} & $6 \mathrm{~m} / \mathrm{s}$ & -0.01 & 0.11 & -0.02 & $6 \mathrm{~m} / \mathrm{s}$ & 0.00 & 0.04 & 0.00 & $6 \mathrm{~m} / \mathrm{s}$ & 0.00 & 0.04 & 0.00 \\
\hline & & $8 \mathrm{~m} / \mathrm{s}$ & -0.02 & 0.00 & 0.01 & $8 \mathrm{~m} / \mathrm{s}$ & -0.03 & 0.00 & 0.03 & $8 \mathrm{~m} / \mathrm{s}$ & 0.00 & 0.07 & 0.00 \\
\hline & & $10 \mathrm{~m} / \mathrm{s}$ & -0.04 & 0.00 & -0.11 & $10 \mathrm{~m} / \mathrm{s}$ & -0.03 & 0.03 & -0.06 & $10 \mathrm{~m} / \mathrm{s}$ & 0.02 & 0.07 & -0.04 \\
\hline
\end{tabular}

(1) Numerical simulation with computational fluid dynamics allows calculating wind speed, temperature, and heat radiation at distinct locations under different operation conditions of air-conditioning systems that it can be applied to the thermal comfort assessment of offices.

(2) From the analyses, the PMV difference values between full-factorial method and Taguchi methods, under same control conditions, do not exceed 0.11 , proving that Taguchi methods could replace fullfactorial methods for thermal comfort assessment.

(3) According to the factor analysis, the importance of design parameters is sequenced as location of airconditioner, outlet air speed of air-conditioner, temperature of air-conditioner, and outdoor temperature. 
(4) The higher simulation efficiency can be derived by introducing Taguchi method. Compared to the fullfactorial method, the time of computational simulation is only $1 / 9$ for four-factor experiment.

Such a research result allows interior designers and mechanical engineers to predict the interior thermal comfort in the beginning of design, through computer simulation and additive model in Taguchi methods.

\section{Conflict of Interests}

The authors declare that there is no conflict of interests regarding the publication of this paper.

\section{References}

[1] A. Andris and V. S. Steven, "Thermal Comfort," PLEA notes, 2007.

[2] A. P. Gagge, "The linearity criterion applied to partitional calorimetry," The American Journal of Physiology, vol. 116, pp. 656-668, 1936.

[3] P. O. Fanger, Thermal Comfort, Krieger, Melbourne, Fla, USA, 1982.

[4] V. S. Steven, Introduction to Architectural Science: The Basis of Sustainable Design, Elsevier, New York, NY, USA, 2nd edition, 2008.

[5] S.-L. Lin, S.-M. Wei, C.-H. Huang, and W.-K. Chen, "Thermal comfort study of an air-conditioned presentation room in Taiwan," Journal of Architecture, vol. 65, pp. 125-138, 2008.

[6] M.-J. Cheng, J.-H. Lo, and L. Jiann-Fong, "A field study of thermal comfort for the campus outdoor environment," Journal of Architecture, no. 69, pp. 1-16, 2009.

[7] Y. Cheng, J. Niu, and N. Gao, "Thermal comfort models: a review and numerical investigation," Building and Environment, vol. 47, no. 1, pp. 13-22, 2012.

[8] W.-H. Chiang, C.-Y. Wang, and J.-S. Huang, "Evaluation of cooling ceiling and mechanical ventilation systems on thermal comfort using CFD study in an office for subtropical region," Building and Environment, vol. 48, no. 1, pp. 113-127, 2012.

[9] Y.-T. Chou and S.-Y. Hsia, "Thermal comfort estimation on indoor space using computational fluid dynamics-a case study of small office room," Applied Mechanics and Materials, vol. 353354, pp. 3015-3019, 2013.

[10] A. R. Ismail, M. R. A. Rani, Z. K. M. Makhbul, K. Sopian, and B. M. Deros, "Thermal comfort assessment and optimization of environmental factors by using Taguchi method," American Journal of Applied Sciences, vol. 6, no. 9, pp. 1731-1741, 2009.

[11] F. Chlela, A. Husaunndee, C. Inard, and P. Riederer, "A new methodology for the design of low energy buildings," Energy and Buildings, vol. 41, no. 9, pp. 982-990, 2009.

[12] ISO 7730, Moderate Thermal Environments-Determination of the PMV and PPD Indices and Specification of the Conditions for Thermal Comfort, International Organization for Standardization, Geneva, Switzerland, 1995.

[13] ASHRAE Standard 55, Thermal Environmental Conditions for Human Occupancy, American Society of Heating, Refrigerating and Air-Conditioning Engineers, Atlanta, Ga, USA, 2004.

[14] B. W. Olesen and G. S. Brager, "A better way to predict comfort," ASHRAE Journal, vol. 46, no. 8, pp. 20-28, 2004.
[15] H.-H. Lee, Taguchi Methods: Principles and Practices of Quality Design, Gau Lih Book, Taipei, Taiwan, 2011. 


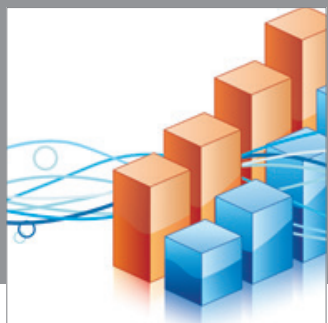

Advances in

Operations Research

mansans

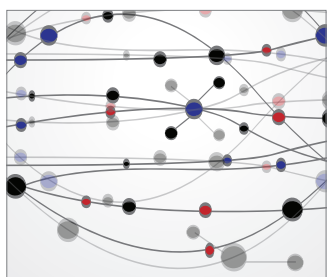

The Scientific World Journal
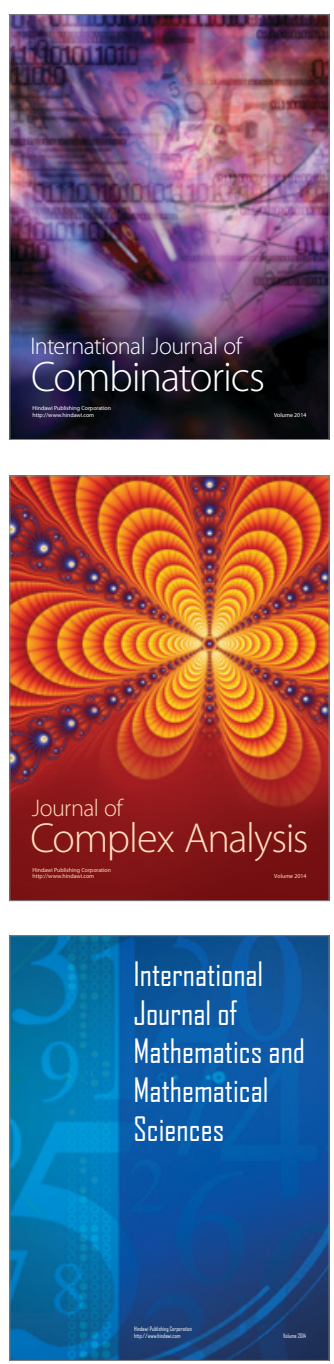
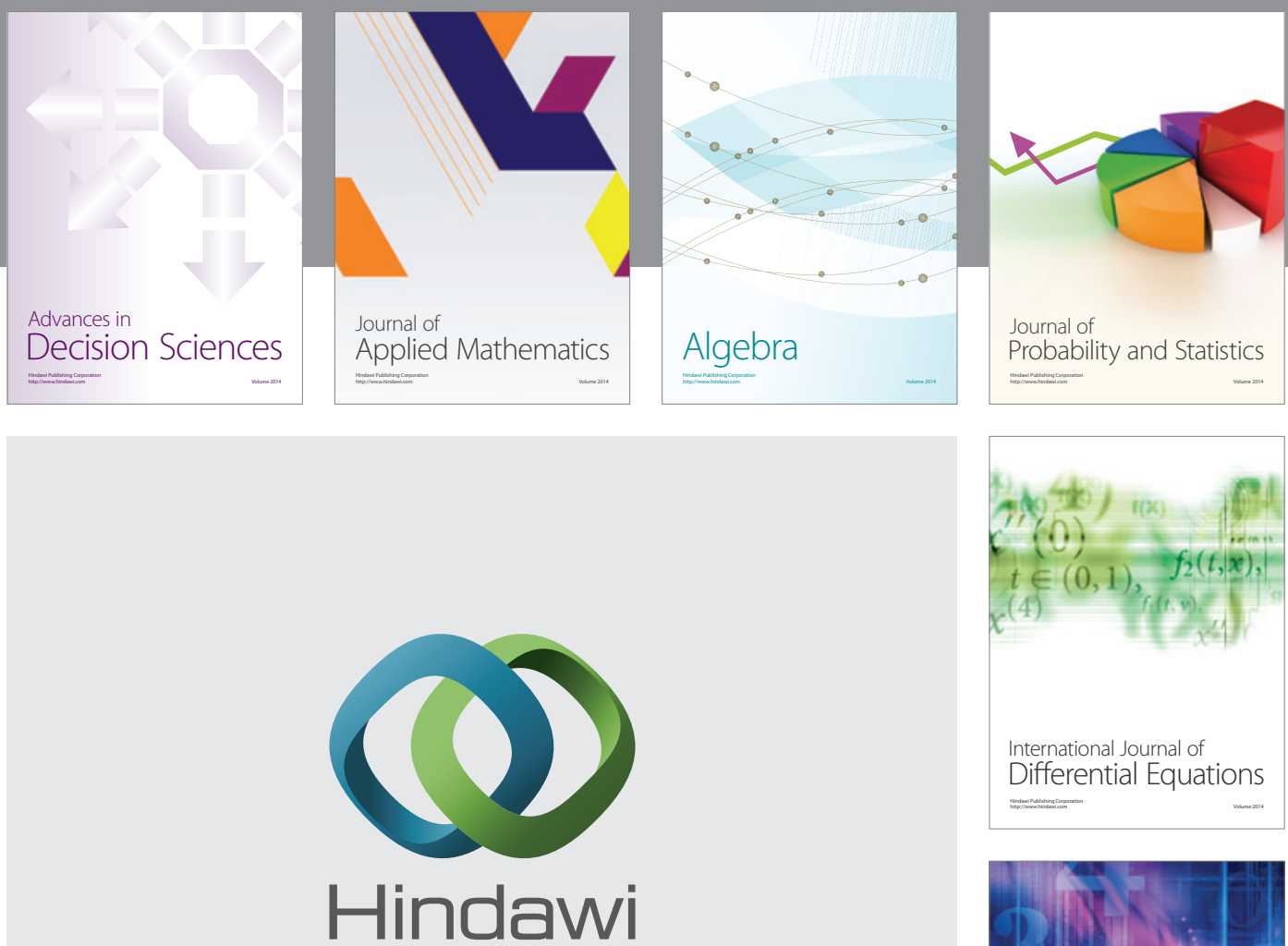

Submit your manuscripts at http://www.hindawi.com
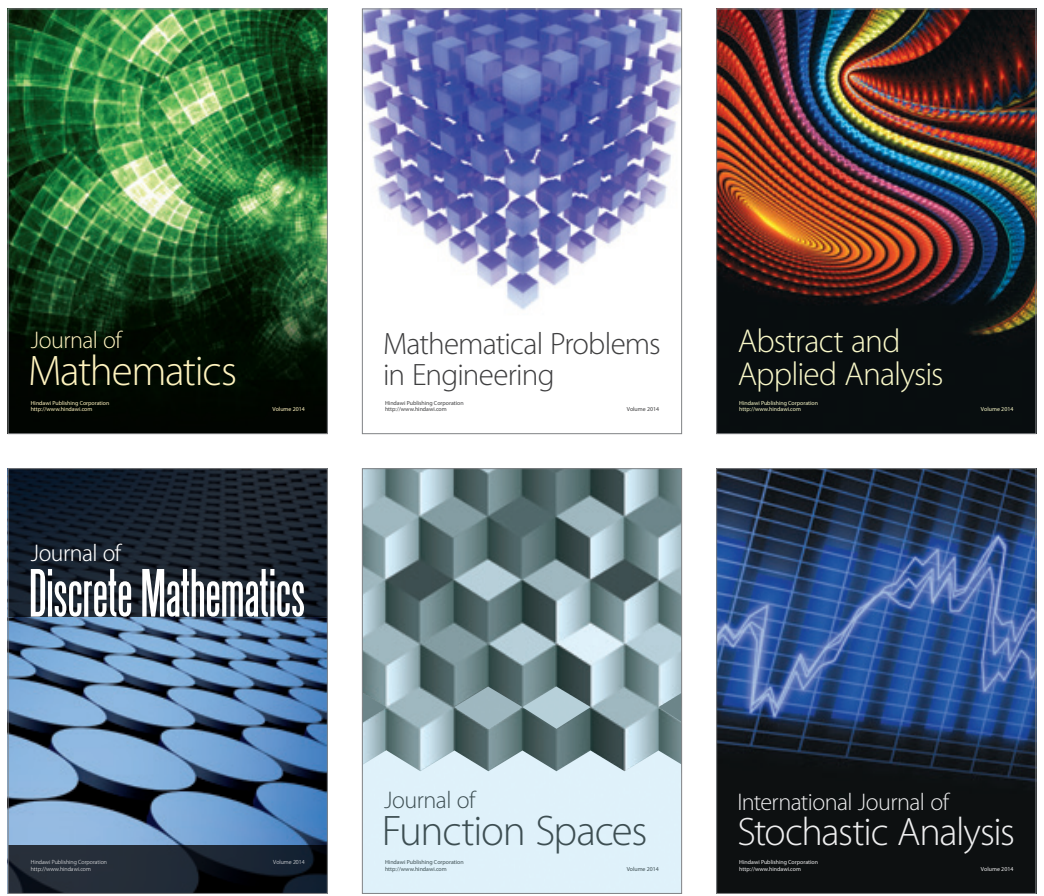

Journal of

Function Spaces

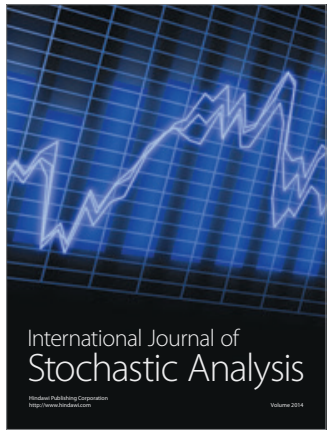

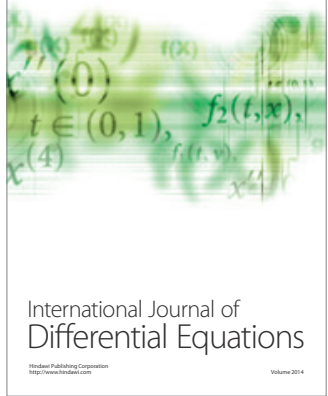
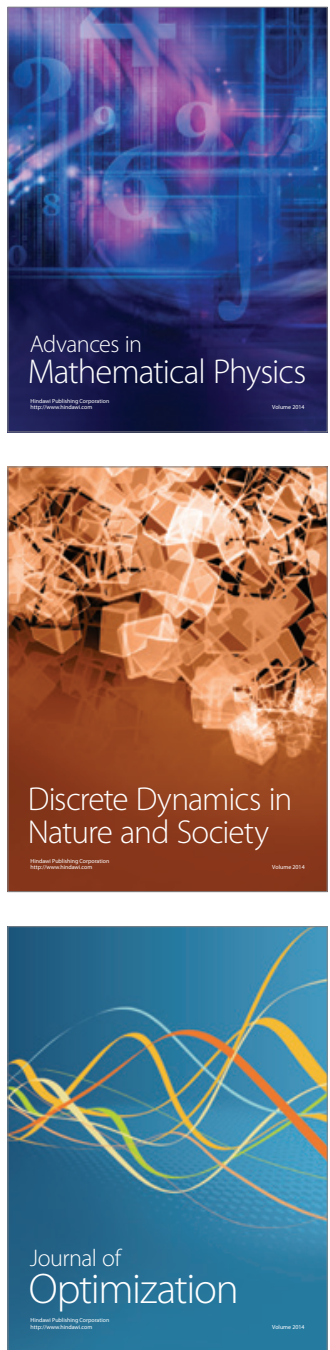